\title{
E-Commerce And Small Business Enterprise Some Evidence From Northern New Jersey
}

Muroki F. Mwaura, (E-mail:mwauram@wpunj.edu), William Paterson University Andrew B. Nyaboga, (E-mail:nyabogaa@wpunj.udu), William Paterson University

\begin{abstract}
The purpose of this research was to investigate the extent to which small businesses in Northern New Jersey are prepared for e-commerce. The Internet has changed the market place and the face of business more dramatically than any other technological innovation since the Industrial Revolution. In the last ten years, the Internet has changed and fundamentally restructured business to business, business to consumer and consumer to consumer relationships. Internet based commerce is estimated to be growing at the rate of $200 \%$ per annum and the volume of Internet commerce is estimated to exceed \$2 trillion by 2003.
\end{abstract}

\section{Introduction}

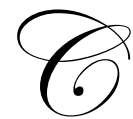

omputers have revolutionized collection, processing, transmission, storage and retrieval of information. There are several terms used to describe this revolution such as Information Technology, Information and Communications Technology, Digital Revolution, Digital Divide, etc. that are used interchangeably to describe this phenomenon. The access to computers and subsequently information technology has altered the way society functions at global, local, and personal levels. However, with every technological revolution comes the possibility that some will be left behind. The underlying disparities on access to information technology are real, both within and among countries. In the mid-1990s the U.S. National Telecommunications and Information Administration (NTIA) popularized the term "digital divide" to describe this phenomenon. The digital revolution has altered the way society functions at global, local, and personal levels. The phrase soon became used in an international context as well, to describe the status of information technology from country to country. Digital divide has many perspectives ranging from global to local geographical delineations. Literature on digital divide traverses many disciplines and studies have been done using a wide variety of variables such as, have and have-nots, literate and illiterate, professional and non-professional, men and women, rich and poor, black and white, rural and urban, small versus large businesses.

\section{Literature Review}

The Benton Foundation, which promotes the public-interest use of communications technology, reports that by late 2001, 80 percent of American families with annual household income greater than $\$ 75,000$ were online, compared with 25 percent of the poorest U.S. families. Total home Internet access was 55 percent for whites, 31 percent for African-Americans and 32 percent for Hispanics. Looking at the international picture, in most African countries less than 1 percent of the population is online. Not surprisingly, such disparity correlates highly with other measures of social and economic inequality. In the year 2000, it was estimated that $36 \%$ of the world population has access to the Internet ( N. Parvathama, Information Technology and Libraries, March, 2003). Because "digital divide" traverses so many variables, the simply binary description of the divide fails to do justice to the complex realities of various people's access to the use of digital technology. There is no one single measure that can be used to describe the extent to which "digital divide" exists between richer and poorer households, whites and non-whites, urban and rural areas, men and women, developed and developing countries, etc. For example, an American who surfs the Internet on a computer at a local library once a month might be considered to be a digital "have-not," 
whereas someone in a developing country with the same profile would be a "have." Indeed, couching the condition in black-and-white terminology can lead those attempting to deal with technological inequities down the wrong path.

The assumption that providing access to computers and information technology could solve the issues posed by "digital divide" has been discounted as inadequate in terms of solving computer illiteracy. In the academic circles this perspective is referred to as "Technological Determinism". The basic precept of this approach is that the mere presence of technology leads to the utilization of the technology. Thus, the implication is that the presence of a computer will by itself provide a solution to the technological illiteracy. The following examples are cited. Newt Gingrich while he was the speaker of the house once suggested that the government provide a laptop computer for every child in America without offering a solid plan for the utilization of the computer. Bill Gates donated computers to small rural town libraries across America with the expectation that connecting the rural communities tot the Internet would stem the migration of rural youth to urban centers.

Governments, private sector, foundations and charities have spent millions of dollars by providing computers to communities perceived to be in need of access to Internet without sufficient attention to the context in which these technologies might be used.

An alternative theory to "Technological Determinism" has been suggested. This theory is based on an eclectic approach called "Social Informatics". The basic precept of this approach is that technology must be considered within a specific context that includes hardware, software, support resources, infrastructure, as well as people in various roles and relationships with one another. This theory has evolved to a new paradigm commonly referred to as "Community Informatics" which takes into account cultural, and political variables that may impact the program.

Research evidence points to the need for careful consideration of all the potential ramifications before applying technology as solution to digital illiteracy. A study by Henry Becker, Harold Wenglinsky and Janet Schofield showed the use of computers in schools is as likely to exacerbate inequality as lessen it. They found that the key issue was not unequal access to computer, but rather the unequal ways that the computers are used. K-12 students from families with high socio-economic status used computers for challenging tasks and experimentation, while students from families with low socio-economic status used computers for less challenging tasks.

\section{Recent Developments in Information Technology}

The public-policy focus on the digital divide is shifting toward broadband Internet access. In a widely cited report, the Department of Commerce (National Telecommunications and Information Administration [NTIA], 2000) finds that in terms of household broadband subscription, black and Hispanic households lag white households, rural areas lag urban areas, and poorer households lag more affluent households. Such findings commingle nonadoption of broadband access by households and nonimplementation of the technology by carriers.

The FCC is also actively involved in monitoring the digital divide, because it is charged by the Telecommunications Act of 1996 to monitor and encourage the "reasonable and timely" deployment of broadband to "all Americans." Although it has not done so yet, the FCC has the authority to add broadband to the list of services supported under Federal Universal Service programs if it deems necessary. Second, because availability is a precondition for access, any analysis of the digital divide must begin with the supply side. A study by FCC in 2000 found that the broadband is less likely to be available in rural areas and lower income neighborhoods. Another major study by James Prieger in 2001 (The Supply Side of Digital Divide: Is there equal availability in the broadband Internet access market? An Economic Inquiry, Western Economic Association, International Annual Meeting April, 2003) expressed concern about broadband availability to minorities, low-income and rural households.

A U.K. Study found that $95 \%$ of urban population has access to Internet and this figure drops to $26 \%$ in market towns and 7\% in rural villages and in remote rural areas this figure drops to 1\% (Nick Loney, 2003). The 
plight of rural areas is not so drastic. Chris Lehner (Rural Telecommunications, May/June 2003) reported that rural communities in Southeastern North Carolina had access to broadband through a partnership of several telecommunications organizations.

\section{Data Analysis}

The results presented in this study focus on availability, access and use of computers and information technology by small businesses in Northern New Jersey. For much of the past decade, policy leaders and social scientists have grown increasingly concerned about a societal split between those with and those without access to information technology. Several measures are used to assess the extent to which a specific population has access to computers and information technology.

A twenty-item questionnaire was completed by 80 companies located in Northern New Jersey. The majority of these firms are located in Passaic and Bergen Counties. The data analysis will be organized using broad themes with sufficient details to disclose the important characteristics of the sample.

\section{Type Of Business}

Out of the 80 businesses responding to this survey the majority (43 or 54\%) were in service industry. Respondents provided a wide range of services. The majority of services provided were essentially "pure services" such as psychiatry, legal, accounting, medical, taxi and limousine, insurance, financial services, pastoral care, and consulting. Other service businesses represented in the sample, were involved in the sale of goods (limited) and services. The business found in this category were, auto garages, computer services, beauty shops (hair and nail saloons) and restaurants. There were twelve firms or $15 \%$ of the sample involved in manufacturing. One of the manufacturing firms was a major supplier of building sand, ballast and crushed rock. Other small manufacturing firms were in food processing, baked goods, pharmaceuticals, and cabinetry. Thirteen firms were in retail and wholesale trade. These firms consisted of auto dealerships, flower shops, and grocery stores. Several firms could not clearly fall into any of the categories indicated in the instrument and they described their business as "other". Some examples of these businesses were motels, car rentals, public and private schools.

\section{Types of Business Ownership}

Five types of business ownership were listed in the survey instrument. All the respondents, except 4 were able to classify themselves into one of the five categories. Out of the 80 respondents, 44 or $55 \%$ classified themselves as corporations. The other ownership types were as follows: S-Corporations 12; C-Corporations 4; Partnerships 7; Sole Proprietorships 9; other 4. The four firms that classified themselves as "other" raise an interesting question because every business entity must fit into one of the five categories unless it is a government entity.

\section{Computer Ownership}

The majority of the respondents (94\%) owned a computer. Three businesses did not own a computer and data was missing for 2 respondents.

\section{Internet Connection}

There were 68 firms or $85 \%$ of respondents were connected to the Internet. Twelve respondents were not connected to the Internet. Among the firms that had Internet connection, $72 \%$ had been connected for five years or less and 28\% had been connected for more than five years. Five firms were connected for more than 10 years. The majority of the respondents (56\%) used Internet Explorer as their main Internet browser. The next most popular browser was AOL with 9 respondents or $11 \%$ of respondents. Other browsers used were Juno, Yahoo, Earthlink.Net, MSN, and Verizon.Net. The majority of the firms (64\%) have a website and the remaining $36 \%$ do not have a website. 
One of the concerns that this study wanted to address was to obtain information regarding the cost of Internet connection. Although, there is no formal hypothesis postulated in this study, it would have appeared logical to associate lack of Internet connection to the cost of the service. The respondents were asked to indicate the annual cost of Internet connection. The figures given ranged from $\$ 25$ to $\$ 244,000$. The approximate median cost of Internet connection was $\$ 700$. It would appear that the cost of Internet connection for the majority of firms was not excessive. Only 7 firms paid more than $\$ 10,000$ per annum.

Overall, the majority of firms (83\%) were satisfied with the services provided by their Internet providers and $87.5 \%$ of the respondents rated themselves as either experienced or comfortable Internet surfers. Only $12.5 \%$ classified themselves as novice surfers.

Although the majority of businesses responding to this survey had Internet connection, few utilized the immense capability of e-commerce. Only 10 respondents or $12.5 \%$ of the sample utilized the Internet for marketing purposes. There was no indication from the respondents that any of them were involved in purchasing of goods and services on the Internet. This response stands in stark contrast with an earlier response where 51 respondents or 64\% of respondents indicated that they had a web site. It would appear that the existence of a web site is not indicative of a firm's utilization of resource available for e-commerce.

\section{Computer Literacy}

This study also sought to establish the extent to which the respondents were computer literate. The respondents were asked to respondent to the following question: "Have you ever taken a computer literacy course? Fifty of the eighty respondents or $63 \%$ percent said "Yes" they had taken a computer literacy course and the other $37 \%$ said "No". The follow-up question asked the respondents if they would be interested in taking a computer literacy course and 58\% responded in the positive and the $42 \%$ said no. A number of computer course were listed and the respondents were asked to indicate what courses they would be interested in taking and the following responses emerged: Word Processing 32; Excel 3; Web design 14; Access 5; Power Point 3; Newsletter Design 2; Accounting, e.g. Peachtree, Quickbooks, 3; Data Base Management 1; Programming, e.g. Java, C++, Basic, 2; Adobe Illustrator 1. It does appear from these responses that a large number of our respondents are interested in taking a computer course.

\section{Conclusion}

The data gathered in this short survey indicates that while many of the small firms surveyed had access to computers, the computers were not used to exploit the immense amount of resources available on the Internet. About a third of respondents did not have access to the Internet and were therefore for all intents and purposes excluded from Internet commerce. Would it be appropriate, therefore, to conclude that among small businesses in Northern New Jersey the digital divide is alive and well? I would say yes. E-commerce will continue to grow and when one third of small businesses are not connected to the Internet, and the few that are connected use the Internet only sparingly, this in my view would be a serious hindrance to economic development.

\section{References}

1. $\quad$ Cooper, M. "Disconnected, Disadvantaged, and Disenfranchised: Explorations in the Digital Divide." Consumers Union and Consumer Federation of America Joint Report, online document available at www.consumersunion.org/pdf/disconnect.pdf, 11 October 2000.

2. $\quad$ Elkins, D. J. "Globalization, Telecommunication, and Virtual Ethnic Communities." International Political Science Review, 18(2), 1997, 139-52.

3. $\quad$ Faulhaber, G. R., and C. Hogendorn. "The Market Structure of Broadband Telecommunications." Journal of Industrial Economics, 48(3), 2000, 305-29.

4. Federal Communications Commission. Deployment of Advanced Telecommunications Capability Second Report. FCC 00-290. Online document available at www.fcc.gov/Bureaus/Common_Carrier/Orders/

5. 2000/fcc00290.pdf, August 2000a. 
6. Federal Communications Commission, Common Carrier Bureau, Industry Analysis Division. High-Speed Services for Internet Access: Subscribership as of June 30, 2000. Online document available at www. fcc.gov/Bureaus/Common_Carrier/Reports/FCCState_Link/IAD/hspd1000.pdf, October 2000b.

7. Federal Communications Commission, Federal-State Joint Board on Universal Service. Universal Service Monitoring Report. Online document available at www.fcc.gov/Bureaus/Common Carrier/Reports/ FCCState_Link/Monitor/mrs01-0.pdf, October 2001.

8. Gabel, D., and F. Kwan. "Accessibility of Broadband Telecommunication Services by Various Segments of the American Population," in Communications Policy in Transition: the Internet and Beyond, edited by B. M. Compaine and S. Greenstein. Cambridge: MIT Press, 2001, 295-320.

9. Gillett, S. E., and W Lehr. "Availability of Broadband Internet Access: Empirical Evidence." Manuscript, September 1999.

10. $\quad$ National Association of State Telecommunications Directors. "Our Digital Nation: Separate and Unequal?" NASTD Backgrounder, 4(5), 2000, 14.

11. National Telecommunications and Information Administration. Falling through the Net: Toward Digital Inclusion: A Report on Americans' Access to Technology Tools. Online document available at www.ntia.doc.gov/ntiahome/fttn00/contents00.html, October 2000.

12. Olson, D. C. "Open Access on Internet High Seas: Where the FCC Is Loathe to Sail." Journal of Municipal Telecommunications, 1(1), April 1999. Available online at munitelecom.org/vlil/Olson.html.

13. Prieger, James E. "The Supply Side of the Digital Divide: Is There Redlining in the Broadband Internet Access Market?" Working Paper 01-16, AEIBrookings 
Notes 